\title{
DEVELOPMENT OF TOURISM IN UKRAINE: TRENDS AND FACTORS THAT CREATE THE NEGATIVE IMAGE
}

\author{
Iryna KARABAZA ${ }^{1}$, Tetiana KOZHUKHOVA ${ }^{2}$, Natalia IVANOVA ${ }^{3}$ \\ ${ }^{1,2,3}$ Donetsk National University of Economics and Trade named after Mykhailo \\ Tugan-Baranovsky, Kryvyi Rih, Ukraine
}

Corresponding author e-mail: ikarabaza7@gmail.com

\begin{abstract}
The purpose of the article is to substantiate trends in the tourism activities in Ukraine and factors that create the negative image. The research is based on the dialectical method of scientific knowledge, methods of scientific abstraction, analysis and synthesis (while summarizing the factors that form the negative image of Ukraine and reduce its economic security); comparative analysis (while identifying the trends of tourism activity development in Ukraine during 2011-2017); statistical analysis (while studying the dynamics of the tourism industry in Ukraine during 2014-2017). As a result of the study, the trends of tourism activity development in Ukraine during 2011-2017 have been determined. The factors that form the negative image of Ukraine and reduce its economic security have been determined. The implementation of strategic measures for the development of the Ukrainian tourism industry will create a positive image of the country, stimulate the development of tourism in Ukraine, formation of attractive investment environment and strengthening of the country's economic security.
\end{abstract}

Keywords: Image, Tourism, Tourist activity, Factors

JEL Classification: O52, L83, L88

\section{INTRODUCTION}

The tourism industry makes a special contribution to the country's economic security. For example, in the USA tourism industry contribution to GDP in 2017 amounted to USD 210.7 million, in Spain it amounted to USD 68 million, in France to USD 60.7 million, in the UK to USD 51.2 million, in Poland to USD 12.8 million. Despite Ukrainian natural, recreational and cultural potential, its GDP increased by only USD 1.3 million at the expense of tourism industry enterprises activity in 2017 . The tourism industry barely contributes to increasing the competitiveness of Ukraine in the world market. Hence, in order to ensure economic security it is important to create the positive image of the country by means of tourism activity development, since traditionally the countries that successfully develop tourism, have the highest rates of investment inflows.

While analyzing the indicators characterizing the development of the tourism industry of Ukraine during 2014-2017 (Table 1), it should be noted that the income from tourist services increased by $240.6 \%$, but the number of tour operators and travel agents in 2017 decreased respectively by $25.3 \%$ and $20.4 \%$.

The reducing of the number of participants of tourism activity is a negative phenomenon for the Ukrainian economy caused by the growing uncertainty while doing tourism business 
connected with currency, political and economic risks, and other factors over the years 20142017 (Fig. 1).

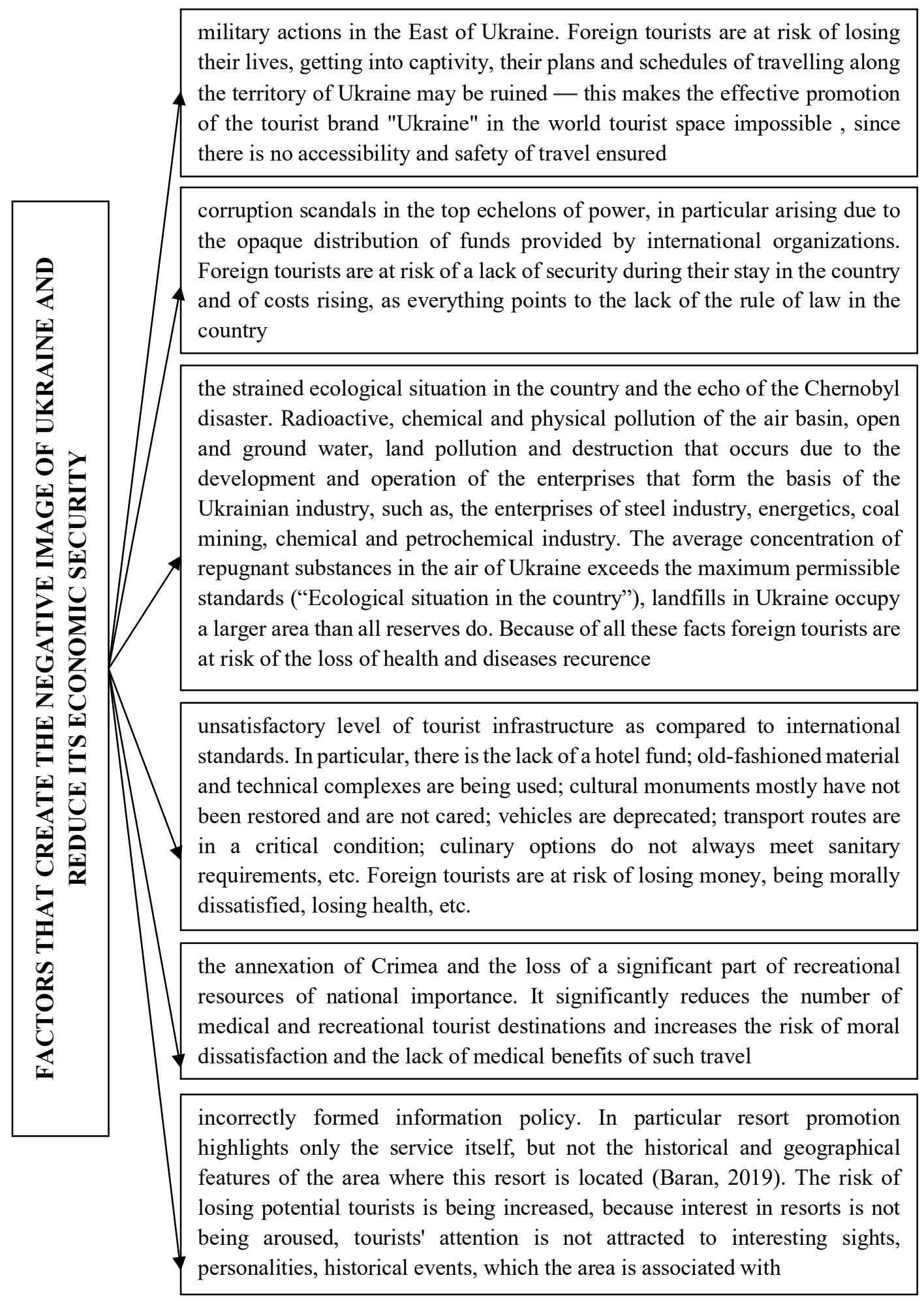

Fig. 1. Factors that create the negative image of Ukraine (Created by authors) 
It leads to loss of jobs and aggravating of unemployment problem (according to Table 1 the number of staff members in the tourism industry declined by $16.7 \%$ during the years 2014-2017) not only at the enterprises of tourist business but in related areas also. For instance, the same happens in the areas of hospitality and transportation. Also it leads to reducing government and local budgets revenue in the form of taxes and fees and to slowing the development of tourism in Ukraine, although this industry could form a significant part of GDP.

Table 1. The main indicators of the tourism industry development in Ukraine

\begin{tabular}{|c|c|c|c|c|c|c|c|c|}
\hline Index & 2014 & 2015 & $\begin{array}{l}\text { Growth } \\
\text { rate, } \% \\
2015 \text { to } \\
2014 \\
\end{array}$ & 2016 & $\begin{array}{l}\text { Growth } \\
\text { rate, } \% \\
2016 \text { to } \\
2015 \\
\end{array}$ & 2017 & $\begin{array}{c}\text { Growth } \\
\text { rate, } \% \\
2017 \text { to } \\
2016 \\
\end{array}$ & $\begin{array}{c}\text { Growth } \\
\text { rate, \% } \\
2017 \text { to } \\
2014 \\
\end{array}$ \\
\hline $\begin{array}{l}\text { The number of } \\
\text { participants of } \\
\text { tourism activity, } \\
\text { measured in } \\
\text { unites including }\end{array}$ & 2198 & 1785 & $-18,8$ & 1838 & 3 & 1743 & $-5,2$ & $-20,7$ \\
\hline Tour operators & 667 & 500 & -25 & 552 & 10,4 & 498 & $-9,8$ & $-25,3$ \\
\hline Travel agent & 1473 & 1228 & $-16,6$ & 1222 & $-0,5$ & 1172 & $-4,1$ & $-20,4$ \\
\hline $\begin{array}{l}\text { Average number } \\
\text { of staff members, } \\
\text { people }\end{array}$ & 9834 & 8086 & $-17,8$ & 8545 & 5,7 & 8190 & $-4,2$ & $-16,7$ \\
\hline $\begin{array}{l}\text { Tourism services } \\
\text { income, UAH } \\
\text { mln. }\end{array}$ & 5432,7 & 4797,7 & $-11,7$ & 11522,5 & 140,2 & 18503,0 & 60,6 & 240,6 \\
\hline $\begin{array}{l}\text { The number of } \\
\text { tourists who have } \\
\text { been provided } \\
\text { with services by } \\
\text { legal entities, } \\
\text { people }\end{array}$ & & & & & & & & \\
\hline $\begin{array}{l}\text { Citizens of } \\
\text { Ukraine }\end{array}$ & 2200339 & 1800277 & $-18,2$ & 2216323 & 23,1 & 2365424 & 6,7 & 7,5 \\
\hline Foreigners & 16618 & 14550 & $-12,4$ & 33784 & 132,2 & 38563 & 14,1 & 132,1 \\
\hline
\end{tabular}

Note: Created by authors based on "The main indicators of the tourism industry development in Ukraine".

The income from tourism activity in Ukraine in 2017 is 3.4 times higher than in 2014 primarily because of the growth of the exchange rate. Thus, as of January 1, 2014, the euro/hryvnia NBU rate was UAH 11.04 per euro ("NBU exchange rate for January 1"), and at the beginning of 2017 the euro/hryvnia rate was UAH 28.42 per euro. Therefore, the growth of income from tourism activity through this extensive factor shouldn't be considered as a positive phenomenon.

While analyzing the change in the number of participants of tourism activity and tourists dynamics by regions of the country (Table 2), it should be concluded that during the last five years the number of tour operators and travel agencies mainly declined in the area of hostilities - Donets'k region - by $89.7 \%$ — and in the front-line regions Dnipropetrovs'k (by $18 \%$ ) and Kharkiv regions (by $11.1 \%$ ). 
Table 2. The number of tourists who have been provided with services by tour operators and travel agents by regions of Ukraine

\begin{tabular}{|l|c|c|c|c|c|c|}
\hline \multicolumn{1}{|c|}{ Regions } & $\mathbf{2 0 1 1}$ & $\mathbf{2 0 1 4}$ & $\mathbf{2 0 1 5}$ & $\mathbf{2 0 1 6}$ & $\mathbf{2 0 1 7}$ & $\begin{array}{c}\text { Growth rate (\%) } \\
\text { 2017 relative to 2011 }\end{array}$ \\
\hline Dnipropetrovs'k Region & 397 & 118 & 294 & 322 & 325 & -18 \\
\hline Donets'k Region & 408 & 45 & 23 & 33 & 42 & $-89,7$ \\
\hline Lviv Region & 230 & 143 & 221 & 272 & 282 & 22,6 \\
\hline Odesa Region & 261 & 172 & 245 & 268 & 264 & 1,1 \\
\hline Kharkiv Region & 296 & 104 & 264 & 255 & 263 & $-11,1$ \\
\hline Kyiv & 885 & 1045 & 888 & 948 & 923 & 4,3 \\
\hline
\end{tabular}

Note: Created by authors based on "The main indicators of the tourism industry development in Ukraine".

The reduction of the number of tour operators and travel agencies in Ukraine, and, consequently, reduction of the number of staff members in the tourism and related industries, reduction of revenues to the budgets in the form of taxes and fees and of the revenue part of the country's GDP and the decline in the country's economic security are driven by the following factors: military actions in the East of Ukraine and constant provocations in the regions bordered by Russia in the Eastern Ukraine; corruption scandals in the top echelons of power; the strained ecological situation in the country and the echo of the Chornobyl disaster; unsatisfactory level of tourism infrastructure; the annexation of Crimea and the loss of a significant part of recreational resources of national importance; incorrectly formed information policy (Fig. 1).

In addition, the factor of increased risk of tourists' life and health injury causes the slowdown in the tourism industry development in such promising area as Odesa region with its centuries-old historical, cultural and recreational traditions. The number of participants of tourism activity in this region increased only by $1.1 \%$ during the last five years, and the number of tourists who visited the region during 2011-2017 decreased by $4.9 \%$ (Table 3 ). During 2011-2017 the redeployment of tourist traffic in Ukraine to Lviv and Dnipropetrovs'k regions and the city of Kyiv has been discernibled; tourist traffic in these areas respectively increased by $36.1 \%, 17.2 \%$ and $112 \%$.

Table 3. The number of tourists who have been provided with services by tour operators and travel agents, by regions of Ukraine

\begin{tabular}{|l|c|c|c|c|c|}
\hline \multicolumn{1}{|c|}{ Region } & $\mathbf{2 0 1 1}$ & $\mathbf{2 0 1 5}$ & $\mathbf{2 0 1 6}$ & $\mathbf{2 0 1 7}$ & $\begin{array}{c}\text { Growth } \\
\text { rate, } \%\end{array}$ \\
\hline $\begin{array}{l}\text { Dnipropetrovs'k } \\
\text { Region }\end{array}$ & 64462 & 46121 & 57770 & 75526 & 17,2 \\
\hline Donets'k Region & 88461 & 3297 & 10874 & 9231 & $-89,6$ \\
\hline Lviv Region & 128709 & 112472 & 181827 & 175150 & 36,1 \\
\hline Odesa Region & 76066 & 45809 & 59077 & 72302 & $-4,9$ \\
\hline Kharkiv Region & 74038 & 31233 & 40429 & 51929 & $-29,8$ \\
\hline Kyiv & 944917 & 1501985 & 1841021 & 2006088 & 112 \\
\hline
\end{tabular}

Note: Created by authors based on "The main indicators of the tourism industry development in Ukraine".

Thus, it is necessary to highlight the following trends in the tourism activities development in Ukraine during 2011-2017:

- aggravation of the risks of reducing competitiveness and economic security of the country as related to the tourist sphere of economic activity; 
- growth of income from the provision of tourist services caused by the exchange rate fluctuations and the inflation growth in the country along with the reduction of the tour operators and travel agents number;

- slowing down the activity of the tourism industry development and reducing the number of tour operators and travel agencies in the areas that were among the leaders of the tourism industry - Dnipropetrovs'k and Kharkiv regions, along with almost complete closing up of tourism business in Donets'k region;

- redeployment of tourist traffic in the country from Donets'k and Odesa regions to Lviv, Dnipropetrovsk regions and the city of Kyiv.

It should be noted that in such conditions, the brand "Ukraine" in the world market has a negative impact on the perception of the country not only by tourists, but also by foreign investors, hosts of international forums, games, etc. In a situation where foreign investment is one of the keys to the transition to effective innovation-driven development and ensuring long-term economic security of Ukraine, the formation of Ukraine's tourism appeal is an issue of great importance. After all, the best advertisement of Ukraine for a foreign investor is the fact that it is a country of safe and high-quality tourism services.

It is essential to provide the state and local budgets aid to small business in the field of tourism by means of providing preferential loans at the expense of special funds, through targeted budget financing on the basis of non-repayable subsidization, celebration of contracts for the development of tourism projects, including green tourism, taking into account reconstruction of cultural and architectural monuments. In order to ensure the country's economic security over the long term, it is necessary to create environment for large-scale investment in infrastructure development, as well as to create the consumer's need to travel and learn more about Ukraine. It is essential to facilitate entry procedures for tourists from Australia, New Zealand, Singapore, China and India and to reduce the visa fee for tourists from other countries, along with establishing security cooperation based on bilateral and multilateral treaties.

\section{REFERENCES}

Baran, H. (2019). Development of tourism in Ukraine: problems and perspectives (Rozvytok turyzmu v Ukraini: problemy ta perspektyvy). Retrieved 10 September, 2019 from http://marker.ua/ua/sotsialnyj-blok/1804razvitie-turizma-v-ukraine-problemy-i-perspektivy/ (in Ukrainian).

Bila, S.O. (2016). Strategic priorities for the tourist services development in Ukraine and prospects for increasing their competitiveness in the world market (Stratehichni priorytety rozvytku turystychnykh posluh $v$ Ukraini ta perspektyvy pidvyshchennia yikh konkurentospromozhnosti na svitovomu rynku). Stratehiia rozvytku Ukrainy — Development Strategy of Ukraine, 1. (in Ukrainian).

Ievtushenko V.A., Rakhman M.S., Manhushev D.V. (2017). International tourism impact on economic development and the image of a particular country (Vplyv mizhnarodnoho turyzmu na ekonomichnyi rozvytok ta imidzh okremoi krainy). Problemy ekonomiky, 2. (in Ukrainian).

Infrastructure of the regions of Ukraine. Priorities for modernization. Analytical treatment (Infrastruktura rehioniv Ukrainy. Priorytety modernizatsii. Analitychne doslidzhennia) (2017). HO «Poliskyi fond mizhnarodnykh ta rehionalnykh doslidzhen», Fond imeni Fridrikha Eberta - NGO "Polissya Foundation for International and Regional Studies", Friedrich Ebert Foundation. Kyiv, 108 (in Ukrainian).

Ivanova, N. (2018). Authentication of the region as the object of economic security in the context of economic development of Ukraine. Revista Galega de Economía, 27(2), 113-124.

Matichyn, Yu.M. (2017). Investment attractiveness of the tourism industry of Ukraine (Investytsiina pryvablyvist turystychnoi haluzi Ukrainy). Ekonomika. Upravlinnia. Innovatsii, 1(20). (in Ukrainian). 
Radio Liberty (2015). Ecological situation in the country. Retrieved from https://www.radiosvoboda.org/a/26916245.html

The main indicators of the tourism industry development in Ukraine (Osnovni pokaznyky rozvytku turystychnoi haluzi Ukrainy). Retrieved from http://www.ukrstat.gov.ua/ (in Ukrainian). 